\title{
Inovasi Pemberdayaan Masyarakat Berbasis Sumber Daya Pangan di Sekitar Wilayah Operasional PT. Pertamina Asset 3 Subang Field
}

\section{(Inovation on Community Empowerment Based on Food Resources Around the Operation Area of PT. Pertamina Asset 3 Subang Field)}

\author{
Sumardjo ${ }^{1,2 *}$, Adi Firmansyah ${ }^{2}$ \\ 1 Departemen Sains Komunikasi dan Pengembangan Masyarakat, Fakultas Ekologi Manusia, \\ Institut Pertanian Bogor, Kampus IPB Darmaga, Bogor 16680. \\ 2 Pusat Kajian Resolusi Konflik, Lembaga Penelitian dan Pengabdian kepada Masyarakat, \\ Institut Pertanian Bogor, Kampus IPB Baranangsiang, Bogor 16144. \\ *Penulis Korespondensi: sumardjo@careipb.or.id
}

\begin{abstract}
ABSTRAK
Wilayah sekitar operasional perusahaan sering ditemukan permasalahan ketidakberdayaan yang berpotensi terjadinya kesenjangan dengan perkembangan perusahaan. Di sinilah perusahaan melalui program CSR dituntut untuk berkontribusi mengatasi kesenjangan sehingga potensi konflik dapat dikelola dengan tepat. Tujuan program pendampingan adalah: merancang pengembangan masyarakat yang secara partisipatif efektif memobilisasi sumber daya lokal, mendorong kemandirian masyarakat melalui usaha-usaha produktif, dan mengembangkan model pelembagaan pengembangan kemandirian masyarakat. Pendekatan pelaksanaan pendampingan dilakukan dengan partisipatif menggunakan metode Participatory Rural Appraisal (PRA). Lokasi program berada di Kabupaten Subang dan Karawang. Program pendampingan telah dilakukan terhadap empat kelompok sasaran, yaitu: kelompok jamur terpadu (10 orang), kelompok ternak domba ( 25 orang), kelompok rumah pangan lestari ( 35 orang), dan kelompok usaha PKBM (66 orang). Program pemberdayaan masyarakat telah menghasilkan inovasi, sebagai berikut: (1) Pengembangan usaha jamur kelompok dengan sistem zero waste, kelompok telah memanfaatkan jerami untuk media tanam jamur; (2) Pengolahan berbagai jenis makanan berbahan dasar jamur, berupa mie jamur dan roti jamur; (3) Pemanfaatan kotoran domba menjadi pupuk organik; (4) Pemanfaatan jerami untuk pakan ternak; (5) Desain kandang inovatif untuk meminimalkan bau kotoran ternak, pencemaran lingkungan, dan mudah dibersihkan; dan (6) Integrasi pendidikan non formal (keaksaraan dan kesetaraan) dengan pendidikan kewirausahaan. Kesimpulan: berdasarkan aspek kemandirian, partisipasi dan jaringan kerja pada kelompokkelompok sasaran, maka kelompok usaha terasi PKBM Assolahiyah merupakan kelompok terpesat perkembangannya, sedangkan kelompok sasaran yang masih sangat terbatas perkembangannya adalah kelompok rumah pangan; dan pemberdayaan masyarakat yang telah dilaksanakan secara partisipatif melalui pendampingan terbukti efektif mendorong lahir dan berkembangnya inovasi-inovasi, dan praktek-praktek baru yang dihasilkan masyarakat.
\end{abstract}

Kata kunci: inovasi pemberdayaan, pendekatan partisipatif, pengembangan masyarakat

\begin{abstract}
Around the company's operations are often found powerlessness problems of society. The company through the CSR program are required to contribute to addressing the problems, so that potential conflicts can be managed. The program objectives are: designing community development that can become self-sufficient rural development model as a development movement program that can mobilize local resources; promoting independence of society through the productive activities, and develop a model of the institutionalization of the development of self-reliance. The program has been implemented by the PRA method, which location in Subang and Karawang. Programs have been conducted on four target groups, namely mushroom group (10 members), the group of sheep ( 25 members), food group (35 members), and Assolahiyah group (66 members). Community empowerment program has resulted in innovation, as follows: (1) Zero waste systems in mushroom group, the group has use of straw for mushroom growing media; (2) Processing of various types of food made from mushrooms, such as mushroom noodles and mushroom bread; (3) Utilization of sheep dung into organic fertilizer; (4) Utilization of straw for animal feed; (5) An innovative enclosure design to minimize the smell of dung, environmental pollution, and easy to clean; and (6) The integration of nonformal education with entrepreneurship education. Conclusion: based on the development of group target (independence, participation, and networking), group Assolahiyah is a fastest, and the lowest is food group; and participatory
\end{abstract}


program, is effectively encouraging the growth and development of innovation/new practices which generated by community.

Keywords: community development, innovation empowerment, participatory approaches

\section{PENDAHULUAN}

Wilayah sekitar operasional perusahaan sering ditemukan permasalahan ketidakberdayaan yang berpotensi terjadinya kesenjangan dengan perkembangan perusahaan. Di sinilah perusahaan melalui program CSR dituntut untuk berkontribusi mengatasi kesenjangan sehingga potensi konflik dapat dikelola dengan tepat. Berbagai upaya pengembangan masyarakat telah banyak dilakukan namun kurang menghasilkan dampak yang signifikan untuk dijadikan contoh bagi pengembangan masyarakat sekitarnya. Hal ini mengingat operasionalisasi suatu perusahaan selain menghasilkan manfaat berupa keuntungan, juga tidak terlepas dari dampak, diantaranya dampak negatif yang berimplikasi pada biaya sosial. PT. Pertamina Asset 3 Subang Field sudah berusaha untuk mengeliminasi dampak negatif tersebut dan berupaya untuk membangun citra positif melalui program $\mathrm{CD}$ yang sifatnya pengembangan masyarakat, maupun program yang sifatnya philantropi.

Pemberdayaan masyarakat merupakan suatu proses perbaikan yang ditujukan untuk memberikan kemampuan kepada siapapun untuk mampu melakukan sesuatu yang bermanfaat. Hikmat (2010) menjelaskan konsep pemberdayaan selalu dihubungkan dengan kemandirian, partisipasi, jaringan kerja, dan keadilan. Salah satu upaya untuk mempercepat proses perbaikan dalam pemberdayaan masyarakat adalah pendampingan. Pendampingan sebagai suatu konsep berkembang dengan adanya kesadaran baru bahwa masyarakat bukanlah pihak yang tidak tahu dan tidak mau maju sebaliknya saat ini mulai dikenali bahwa masyarakat adalah pihak yang mau, memiliki pengetahuan lokal, mempunyai potensi besar, serta kearifan tradisional.

Pendampingan pada dasarnya merupakan upaya untuk menyertakan masyarakat dalam mengembangkan berbagai potensi yang dimiliki sehingga mampu mencapai kualitas kehidupan yang lebih baik (Sumardjo 2014). Kegiatan ini dilaksanakan untuk memfasilitasi pada proses pengambilan keputusan berbagai kegiatan yang terkait dengan kebutuhan masyarakat, membangun kemampuan dalam meningkatkan pendapatan, melaksanakan usaha yang berskala bisnis serta mengembangkan perencanaan dan pelaksanaan kegiatan yang partisipatif.

Dalam pelaksanaan program pendampingan ini diperlukan ketersediaan sumber daya manusia (SDM) yang berkualitas yang mampu berperan sebagai fasilitator, komunikator, dan dinamisator selama program berlangsung dan berfungsi sebagai konsultan sewaktu diperlukan oleh kelompok. Perubahan perilaku masyarakat untuk mandiri dan kreatif dalam mengembangkan usaha produktif merupakan fokus program pendampingan. Tenaga pendamping diharapkan dapat memberikan kaderisasi kepada tokoh di desa di mana ketika program berakhir, keberlanjutan pengembangan masyarakat dapat dilakukan oleh kader yang telah mendapatkan transfer knowlegde ini. Dengan adanya kader desa tersebut juga diharapkan dapat membantu proses kemandirian masyarakat dan desa.

PT Pertamina EP Asset 3 Subang Field mempunyai komitmen yang besar terhadap tanggung jawab sosial dan lingkungan. Untuk mengakselerasi hasil pelaksanaan CSR, PT. Pertamina Asset 3 Subang Filed 2014 bekerja sama dengan CARE LPPM IPB melaksanakan pendampingan program CSR. Tujuan program pendampingan adalah: (1) Berkembangnya inovasi dalam pemberdayaan masyarakat melalui pendampingan; (2) Mendorong kemandirian masyarakat melalui usaha-usaha produktif dalam rangka menciptakan peluang pendapatan; dan (3) Merancang model pengembangan masyarakat secara partisipatif yang efektif memobilisasi sumber daya lokal, mengorganisasi masyarakat, dan kreativitas masyarakat sesuai dengan karakteristik potensi dan permasalahan masyarakat setempat.

\section{METODE PELAKSANAAN}

Pendekatan pelaksanaan program pendampingan dilakukan dengan metode partisipatif, artinya masyarakat ditempatkan sebagai subjek dalam setiap aktivitas kegiatan, mulai dari perencanaan, implementasi, monitoring, maupun evaluasi. Salah satu upaya untuk meningkatkan partisipasi warga masyarakat dalam pengembangan desanya maka diterapkan pola pendekatan sistem pengelolaan bertumpu pada masyarakat (CBMA: community based management 
approach) di dalam setiap kegiatannya. Pola ini, dimaksudkan untuk sedini mungkin berkembang persepsi dan komitmen warga bahwa sesungguhnya merekalah subyek dari setiap kegiatan di desanya. Dengan komitmen dan motivasi ini, ternyata setiap warga berkontribusi secara optimal mewujudkan kemandirian dalam proses pengambilan keputusan, perencanaan, pelaksanaan setiap kegiatan, pemanfaatan hasil, dan penilaian serta keberlanjutannya. Pengambilan keputusan dan perencanaan merupakan komponen penting dalam pola pendekatan pemberdayaan masyarakat. Pada proses penyusunan perencanaan di antara warga desa terjadi saling tukar informasi atau data tentang potensi sumber daya dan kebutuhan real masyarakat. Berdasarkan realitas yang ada, warga dapat mengidentifikasi masalah di lingkungannya serta merumuskan alternatif pemecahannya. Dengan demikian, hasil keputusan dan perencanaan bersama tersebut, merupakan cerminan dari keinginan yang didasarkan pada kebutuhan dan kemampuannya. Adapun tahapan pelaksanaan program ditampilkan pada Gambar 1.

Program pendampingan dilakukan terhadap empat kelompok sasaran, yaitu kelompok jamur terpadu (10 orang), kelompok ternak domba (25 orang), kelompok rumah pangan lestari (35 orang), dan kelompok usaha PKBM (66 orang). Kriteria utama masyarakat sasaran yang bisa menjadi anggota kelompok adalah masyarakat yang terkategori miskin sesuai rekomendasi RT/RW setempat. Lokasi kegiatan berada di Desa Cidahu, Kabupaten Subang, Desa Karangligar, Pasirukem, dan Sukamulya Kabupaten Karawang.

\section{HASIL DAN PEMBAHASAN}

\section{Pengembangan Inovasi Pemberdayaan Masyarakat}

Berdasarkan hasil pengkajian kebutuhan program, maka terdapat empat program utama CSR yang digulirkan pada tahun 2014, antara lain: (1) Kampung Jamur Merang Terpadu; (2) Ternak Domba Terpadu; (3) Pendampingan Belajar Usaha Mandiri (Jauhari) Berbasis PKBM Assolahiyah; dan (4) Rumah Pangan Lestari. Berikut deskripsi masing-masing program tersebut.

\section{Jamur Merang Terpadu}

Program jamur terpadu ini telah dimulai PT. Pertamina Asset 3 Subang Filed tahun 2012. Pada awal kegiatan dimulai dengan pembentukan kelompok, pembangunan infrastruktur, dan peningkatan pengetahuan SDM calon petani jamur (Yayasan Sekar Mandiri 2013). Pembentukan kelompok ini ternyata: (1) Memudahkan para petani jamur mengorganisasikan diri, baik dalam hal pelaksanaan, pengorganisasian,

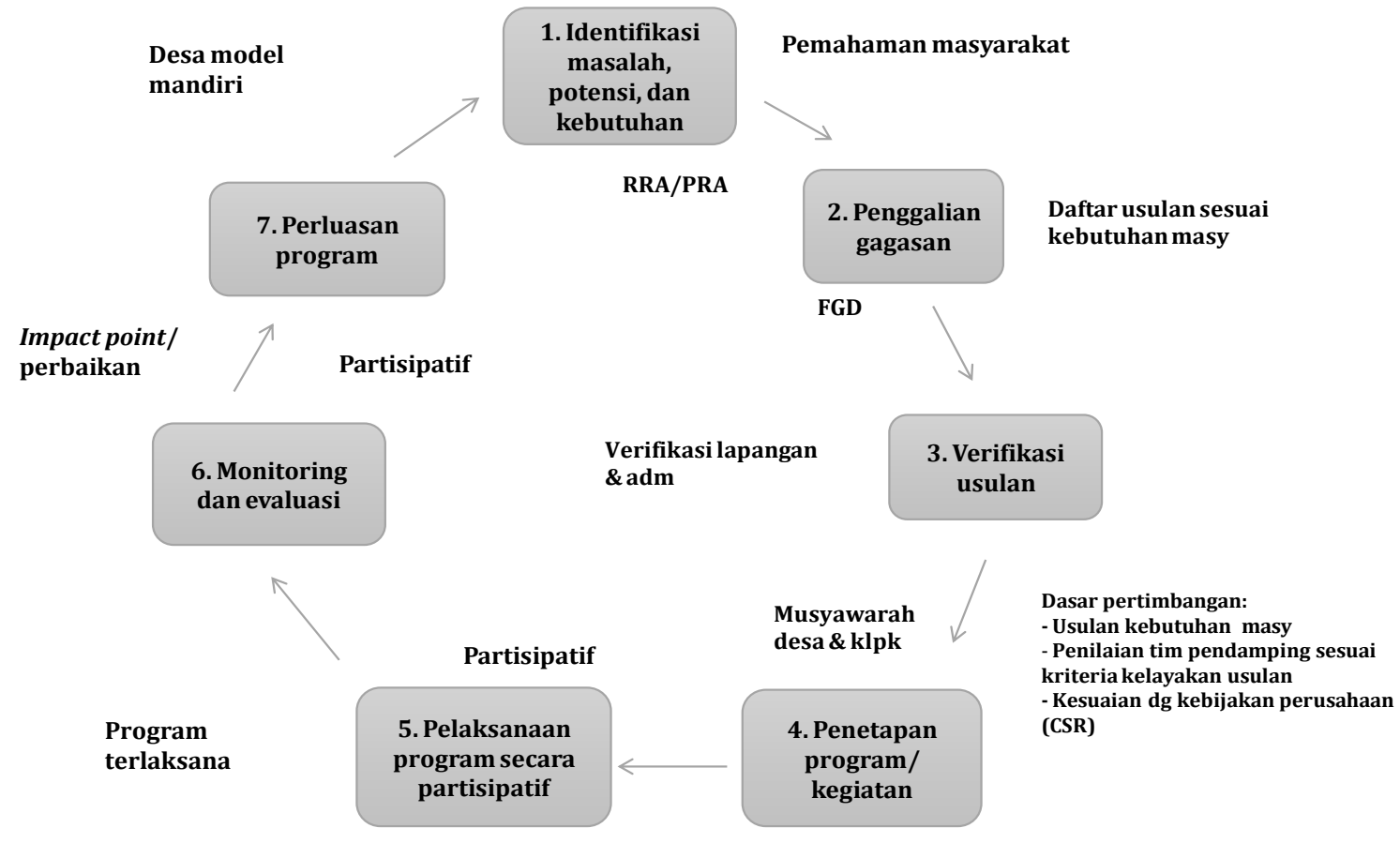

Gambar 1 Tahapan proses pendampingan program pendampingan. 
maupun penanganan kegiatan-kegiatan kelompok; dan (2) Efektif menjadi wadah pembelajaran bagi petani jamur untuk mengatasi kebutuhan dan permasalahan dari masing-masing anggota sehingga menjadi lebih berdaya.

Setelah kelompok terbentuk, dilakukan pelatihan sederhana tentang dasar-dasar kelompok UKM. Hal ini ternyata cukup membekali para pengurus dan anggota kelompok untuk mengelola kelompok tahap selanjutnya. Pelatihan tersebut dilaksanakan disertai bimbingan kepada para anggota dan pengurus kelompok yang meliputi aspek fungsi, peran, dan tanggung jawab pengurus dan anggota UKM, penguatan aspek administrasi, baik yang menyangkut organisasi dan keuangan UKM. Pendampingan pada aspek kelembagaan lebih difokuskan pada penguatan peran dan tanggung jawab pengurus serta bimbingan dalam pembuatan buku-buku organisasi termasuk pembuatan buku anggota.

Bimbingan terhadap aspek keuangan UKM ternyata: (1) Meningkatkan pemahaman dan motivasi petani jamur tentang pentingnya pencatatan keuangan dan rutinitas tabungan anggota; (2) Meningkatkan motivasi mengangsur pinjaman secara lancar; dan (3) Memahami konsekuensi bagi anggota yang terlambat dalam mencicil pinjaman. Kegiatan lain yang dilakukan selain bimbingan dan pelatihan bagi anggota kelompok, yaitu berupa pendalaman wawasan tentang pengetahuan kelompok diasah melalui diskusi, sharing pengalaman, dan pemikiran di antara anggota kelompok. Topik diskusi menyangkut inovasi budi daya jamur, pengalaman, kebutuhan pelatihan, dan faktor-faktor lain yang berhubungan dengan pengolahan dan pemasaran hasil budi daya jamur merang.

\section{Ternak Domba Terpadu}

Program ini berupa penggemukan dan pembibitan ternak domba yang diintegrasikan dengan pengolahan kotoran dan hasil samping. Juga terintegrasi dengan penanaman tanaman produktif di sekitar kandang. Pendampingan usaha ternak domba yang didampingi oleh tim pendamping dari CARE LPPM IPB. Pemerintah desa juga berperan untuk mengawasi perkembangan kegiatan kelompok. Penyuluh pertanian/peternakan dan dokter hewan setempat berperan untuk mendampingi secara teknis kegiatan usaha ternak. Pengertian terpadu dalam program ini adalah peternak berusaha ternak secara komunal/terpusat di suatu lokasi. Selain berusaha budi daya (penggemukan dan pembibitan), juga terpadu dengan pengolahan kotoran, dan hasil samping lainnya. Terpadu juga dalam hal komoditas, dimana secara bertahap di lokasi kandang akan ditanam tanaman produktif (pangan dan hortikultura). Penyelenggaraan program Ternak Domba Terpadu tahun 2014 dilaksanakan di dua lokasi, yaitu Dusun Wagirsari, Desa Pasirukem, Kecamatan Cilamaya Kulon, Kabupaten Karawang dan Dusun Karang Cagak, Desa Cidahu, Kecamatan Pagaden Barat, Kabupaten Subang.

Tujuan kegiatan ini adalah: (1) Peningkatan kesejahteraan penerima manfaat kegiatan melalui agribisnis ternak domba; (2) Membuka peluang berusaha di bidang peternakan; (3) Mewujudkan kemandirian masyarakat khususnya penerima manfaat; (4) Memperkuat peran kelompok dalam usaha agribisnis domba; dan (5) Sebagai usaha awal perintisan lokasi program menjadi sentra domba mandiri yang memiliki usaha domba dari hulu ke hilir. Adapun sasaran program adalah keluarga dengan kategori rumah tangga miskin (RTM), dengan persyaratan: (1) Punya pengalaman/pernah beternak domba; (2) Belum pernah mendapatkan bantuan program baik dari pemerintah maupun swasta; dan (3) Berminat tinggi untuk terlibat dalam budi daya ternak domba. Dalam pelaksanaan program ini PEP Subang Field melibatkan pihakpihak terkait. Model skematik kemitraan disajikan pada Gambar 2.

Tahap-tahap yang telah dilaksanakan dalam program ini adalah: (1) Seleksi anggota kelompok; (2) Pertemuan awal dengan calon anggota dan pembentukan kelompok; (3) Pembangunan kandang secara gotong royong oleh anggota kelompok; (4) Pengadaan ternak domba; (5) Serah terima kandang dan ternak domba; (6) Pelatihan usaha ternak domba; dan (7) Pelaksanaan pemeliharaan usaha ternak domba. Hasil-hasil pendampingan ternak domba disajikan pada Tabel 1.

\section{Rumah Pangan Lestari}

Kondisi eksisting menunjukkan masih banyak ditemui lahan-lahan pekarangan masyarakat yang belum termanfaatkan secara optimal. Lahan tersebut berupa lahan terbuka maupun semak belukar. Optimalisasi pemanfaatan lahan pekarangan dengan penanaman tanaman sayuran/hortikultura serta tanaman obat, dan lainnya diharapkan bukan saja memberi kesempatan bagi masyarakat untuk menerima tambahan manfaat baik secara ekonomi, kesehatan, ketahanan pangan, maupun dari sisi lingkungan berupa peningkatan persentase penutupan lahan. Keter- 
libatan anggota keluarga dalam pemanfaatan lahan pekarangan bertujuan meningkatkan pendapatan keluarga.

Tujuan kegiatan ini antara lain: (1) Terwujud- nya kawasan rumah pangan lestari; dan (2) Peningkatan pendapatan keluarga. Sasaran kegiatan adalah masyarakat yang berminat mengembangkan lahan pekarangan yang dimiliki di

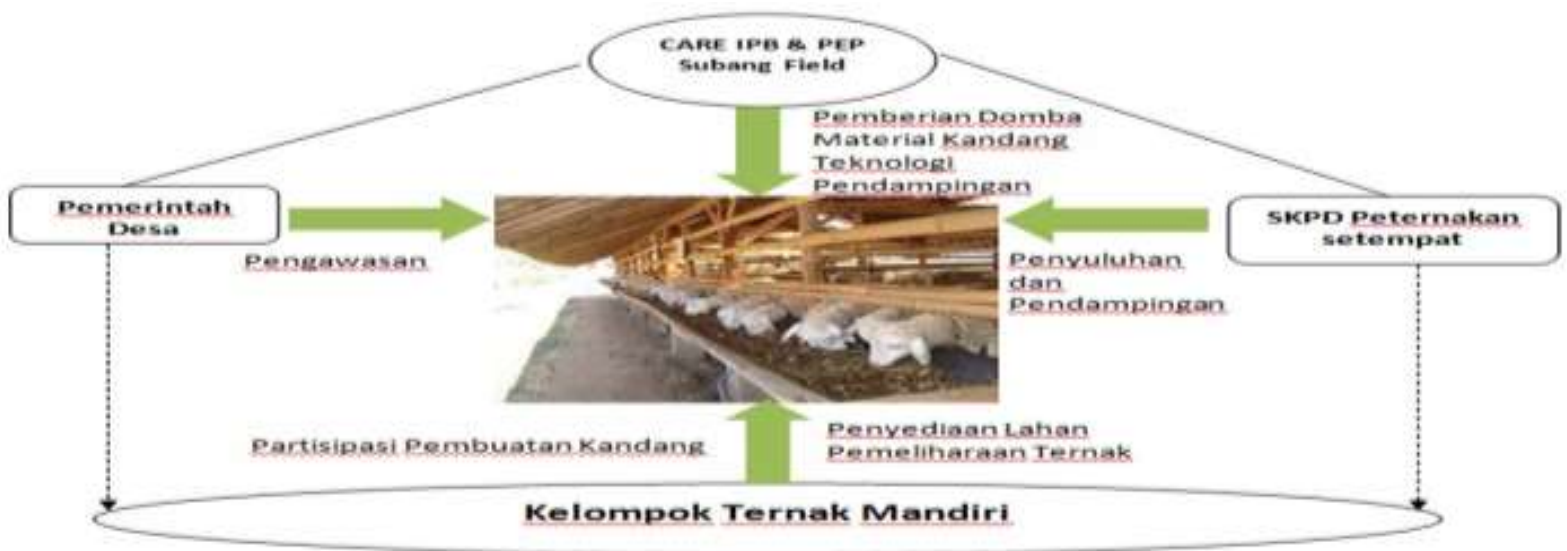

Gambar 2 Model kemitraan program Ternak Domba Terpadu.

Tabel 1 Hasil-hasil program pendampingan ternak domba

\begin{tabular}{|c|c|c|}
\hline Aspek & Pasirukem-Karawang & Cidahu-Subang \\
\hline Bentuk kegiatan & \multicolumn{2}{|c|}{$\begin{array}{l}\text { Usaha ternak secara terintegrasi/kandang komunal dengan pola usaha perguliran ternak } \\
\text { domba. Pertamina memberikan bantuan ternak dan kandang, masyarakat membangun } \\
\text { kandang dan memelihara ternak, CARE IPB memberikan pendampingan melalui sarjana } \\
\text { pendamping. }\end{array}$} \\
\hline Tujuan & \multicolumn{2}{|c|}{ Peningkatan pendapatan, peningkatan pengetahuan, dan keterampilan usaha ternak domba } \\
\hline Lokasi kegiatan & Dusun Wagirsari & Dusun Karangcegak \\
\hline $\begin{array}{l}\text { Penerima } \\
\text { manfaat }\end{array}$ & 15 orang & 10 orang \\
\hline Nama kelompok & Bina Usaha Mandiri & Berkah Mandiri Jaya \\
\hline $\begin{array}{l}\text { Hasil-hasil } \\
\text { kegiatan hingga } \\
\text { saat ini }\end{array}$ & $\begin{array}{l}\text { - Terbentuk kelompok usaha ternak } \\
\text { domba } \\
\text { - Terbangunnya kandang terpadu } \\
\text { - Penyaluran } 20 \text { ekor domba } \\
\text { - Terselenggaranya pelatihan cara be- } \\
\text { ternak yang baik } \\
\text { - Pembuatan Silase (pakan alternatif) } \\
\text { - Produksi pupuk kandang } \pm 10-20 \\
\mathrm{~kg} / \text { minggu } \\
\text { - Penambahan bobot domba peng- } \\
\text { gemukan } \pm 1,2 \mathrm{~kg} / \text { bulan } \\
\text { - Penambahan jumlah anakan } 13 \text { ekor } \\
\text { - Pengenalan nutrisi tambahan pada } \\
\text { pakan berupa ampas tahu } \\
\text { - Pembuatan kebun bibit sayur dan buah } \\
\text { di sekitar kandang }\end{array}$ & $\begin{array}{l}\text { - Terbentuk kelompok usaha ternak domba } \\
\text { - Terbangunnya kandang terpadu } \\
\text { - Penyaluran } 20 \text { ekor domba } \\
\text { - } \text { Terselenggaranya pelatihan cara beternak } \\
\text { - } \text { yang baik } \\
\text { - Pembuatan POC (Pupuk Organik Cair) } \\
\text { Produksi pupuk kandang } \pm 10-25 \mathrm{~kg} / \\
\text { - } \text { Penggu } \\
\text { - } 1,3 \mathrm{~kg} / \text { buhan bobot domba penggemukan } \pm \\
\text { - Penambahan jumlah anakan } 19 \text { ekor } \\
\text { sekitaratan kandang bibit sayur dan buah di } \\
\end{array}$ \\
\hline $\begin{array}{l}\text { Kemitraan } \\
\text { terjalin }\end{array}$ & $\begin{array}{l}\text { Dinas Peternakan Kabupaten } \\
\text { Karawang } \\
\text { - Centre for Alternative Dispute } \\
\text { Resolutions, Regulation \& Policy Ana- } \\
\text { lysis and Community Empowerment, } \\
\text { Lembaga Penelitian dan Pengabdian } \\
\text { kepada Masyarakat, Institut Pertanian } \\
\text { Bogor (CARE, LPPM, IPB) }\end{array}$ & $\begin{array}{l}\text { - Dinas Peternakan, Kabupaten Subang } \\
\text { - Centre for Alternative Dispute Resolutions, } \\
\text { Regulation \& Policy Analysis and Community } \\
\text { Empowerment, Lembaga Penelitian dan } \\
\text { Pengabdian kepada Masyarakat, Institut } \\
\text { Pertanian Bogor (CARE, LPPM, IPB) }\end{array}$ \\
\hline
\end{tabular}


wilayah Desa Pasirjaya dan Karangligar, Kabupaten Karawang serta Desa Dangdeur, Kabupaten Subang. Metode pelaksanaan program antara lain, melalui demonstrasi, pelatihan, pendampingan pembuatan rumah pangan lestari, lomba pekarangan terbaik, pelatihan olahan pangan, dan budi daya tanaman bernilai ekonomi.

Ada lima tahapan yang telah dilaksanakan dalam pelaksanaan program Rumah Pangan Lestari antara lain: 1) Pengadaan kebun bibit induk; 2) Pelatihan budi daya pemanfaatan lahan pekarangan dengan tanaman buah-buahan, sayuran, dan lain-lain; 3) Pengembangan depot pangan minimal di lima keluarga sasaran; 4) lomba pekarangan; 5) Pelatihan olahan pangan; dan 6) Bantuan alat produksi dan pendampingan usaha. Hasil-hasil pemberdayaan disajikan pada Tabel 2.

\section{Pengembangan Jauhari PKBM Assolihiyah Berbasis Usaha Pangan}

Program Belajar Usaha Mandiri (Jauhari) merupakan program yang digagas oleh sebuah lembaga pendidikan non formal atau yang di- kenal dengan PKBM Assolohiyah yang berkedudukan di Desa Pasirjaya, Kecamatan Cilamaya Kulon, Kabupaten Karawang. Tujuan kegiatan ini antara lain memberi peluang peningkatan kapasitas diri bagi masyarakat dan membuka peluang kesempatan berusaha bagi warga belajar. Sasaran kegiatan ini adalah masyarakat putus sekolah serta masyarakat rentan (buta huruf dan keluarga miskin) di Kecamatan Cilamaya Kulon. Sistem/metode pelaksanaan program adalah dengan mengintegrasikan pendidikan kesetaraan ataupun program keaksaraan fungsional dengan kecakapan hidup dengan menginisiasi Kelompok Belajar Usaha (KBU) guna membuka peluang berusaha bagi siswa belajar. Dalam upaya meningkatkan angka partisipasi pendidikan setingkat SD, SMP, dan SMA, maka PKBM juga membekali warga belajar dengan keterampilan dan usaha, salah satunya olahan terasi.

Program usaha terasi super khas Tanjung Baru berbasis potensi lokal PKBM Assolahiyah terletak di Dusun Cilempung dan Tanjung Baru, Desa Pasirjaya, Kecamatan Cilamaya Kulon.

Tabel 2 Hasil-hasil pendampingan program Rumah Pangan Lestari

\begin{tabular}{|c|c|c|}
\hline Aspek & Karangligar-Karawang & Cidahu-Subang \\
\hline Bentuk kegiatan & Inisiasi kegiatan pemanfaatan lahan pekarangan dan peng & golahan pangan \\
\hline Tujuan & $\begin{array}{l}\text { 1) Terwujudnya kawasan rumah pangan lestari; dan } \\
\text { keluarga }\end{array}$ & n 2) Peningkatan pendapatan \\
\hline Lokasi & $\begin{array}{cc}\text { Dusun I } & \text { Dusun Cilempung } \\
\end{array}$ & Dusun Bundar \\
\hline $\begin{array}{l}\text { Penerima } \\
\text { manfaat }\end{array}$ & 10 orang & 10 orang \\
\hline Nama kelompok & Agro Tanjung Baru & Srikandi \\
\hline $\begin{array}{l}\text { Hasil-hasil } \\
\text { kegiatan saat ini }\end{array}$ & 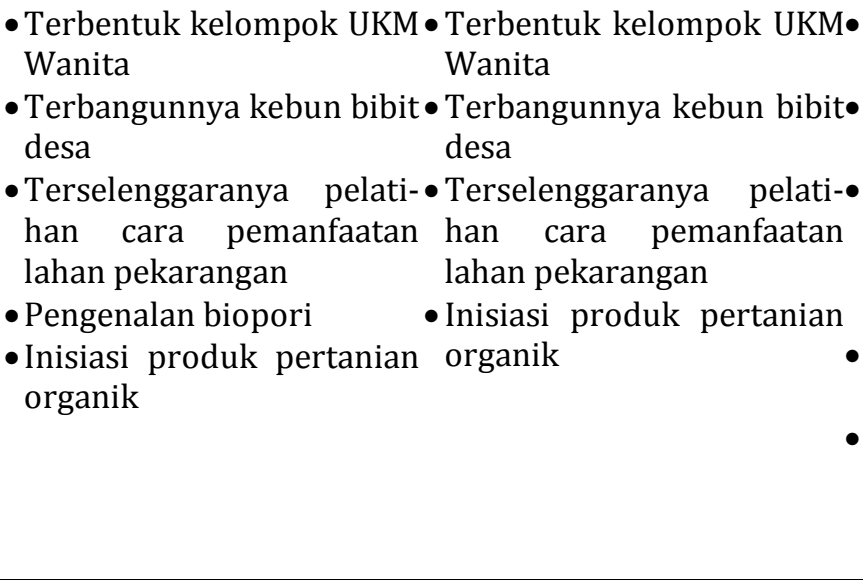 & $\begin{array}{l}\text { Terbentuk kelompok UKM } \\
\text { Wanita } \\
\text { Terbangunnya kebun bibit } \\
\text { desa } \\
\text { Terselenggaranya pelatihan } \\
\text { cara pemanfaatan lahan peka- } \\
\text { rangan dan pelatihan olahan } \\
\text { pangan } \\
\text { Pembuatan inisiasi produk } \\
\text { pertanian organik } \\
\text { Berproduksinya } \\
\text { pengolahan makanan keripik } \\
\text { pisang, kerpik talas, dan sale } \\
\text { pisang }\end{array}$ \\
\hline $\begin{array}{l}\text { Kemitraan } \\
\text { terjalin }\end{array}$ & $\begin{array}{l}\text { Pemerintah Desa Ka-• PKBM Assolihiyah } \\
\text { rangligar }\end{array}$ & $\begin{array}{l}\text { - Dinas Perindustrian Per- } \\
\text { dagangan Kabupaten Subang } \\
\text { - Dinas Kesehatan Kabupaten } \\
\text { Subang } \\
\text { - Dinas Pertanian Kabupaten } \\
\text { Subang }\end{array}$ \\
\hline
\end{tabular}


Letak desa yang berdekatan dengan Pantai Tanjung Baru yang saat ini menjadi objek wisata laut yang ada di Kabupaten Karawang menjadikan potensi besar bagi masyarakat sekitar untuk mendapatkan penghasilan tambahan dari banyaknya pengunjung yang datang untuk berwisata, tapi hal ini tidak berlaku bagi sebagian besar masyarakat nelayan yang berlokasi disekitar objek wisata.

Kebanyakan masyarakat di Dusun Tanjung Baru tertinggal dalam bidang pendidikan dan ekonomi. Dengan alasan demikian PKBM Assolahiyah mengajak masyarakat sekitar untuk membentuk kelompok usaha terasi super khas Tanjung Baru yang bertujuan meningkatkan harga jual terasi yang lebih tinggi dan memperkenalkan produk terasi hasil masyarakat sekitar sebagai produk khas yang dapat dijadikan oleh-oleh khas Tanjung Baru khususnya dan umumnya sebagai produk khas Karawang. Dengan kemasan yang lebih bagus diimbangi peningkatan kualitas produk terasi yang dihasilkan maka terasi yang dihasilkan pun bisa bersaing di pasar yang lebih besar.

Kegiatan ini juga diintegrasikan dengan pendidikan keaksaraan mengingat mayoritas penduduk Tanjung Baru merupakan komunitas buta aksara. Tingginya angka buta aksara di wilayah ini selain disebabkan aksesibilitas wilayah juga disebabkan oleh rendahnya motivasi masyarakat untuk dapat mengakses pendidikan sebagai bekal penghidupan. Oleh karena itu, sasaran kegiatan ini adalah masyarakat usia produktif (20-60 tahun) komunitas buta aksara dan rumah tangga miskin di kawasan Dusun Tanjung Baru dan Cilempung.

Beberapa program yang dilaksanakan PKBM Assolahiyah dalam mengelola usaha terasi super khas Tanjung Baru adalah sebagai berikut:

- Pembentukan kelompok usaha yang diinisiasi dari kelompok keaksaraan fungsional, anggotanya terdiri dari 66 orang (53 perempuan dan 13 laki-laki).

- Pemberian pinjaman dana usaha nelayan melalui kelompok. Pinjaman ini kemudian dibayar dengan bahan baku terasi pada rumah produksi yang dikelola PKBM Assolahiyah. Harga bahan baku tidak berkurang sesuai kesepakatan. Ini bertujuan menaikkan harga bahan baku terasi ke pengepul/bakul lain diluar PKBM.

- Memberikan bantuan alat giling terasi untuk dikelola kelompok masyarakat/nelayan penangkap udang rebon. Alat ini sangat membantu dalam proses membuat terasi karena apabila pengolahan terasi masih menggunakan alat produksi yang masih tradisional akan menyita waktu dan mengurangi kapasitas bahan baku terasi itu sendiri. Dalam sehari nelayan bisa mendapatkan puluhan kilo udang rebon bahan terasi. Jumlah bahan ini tidak bisa dikerjakan dengan cara manual, yaitu ditumbuk tetapi harus menggunakan mesin penggiling (Gambar 3).

Terkait dengan kegiatan ini kemitraan juga sudah dibangun, diantaranya dengan instansi pemerintahan lingkup Kabupaten Karawang seperti dengan Dinas Pendidikan, Dinas Perindustrian dan Perdagangan. Kemitraan juga dibangun dengan pengusaha lokal yang menjadi pasar produk.

\section{Kemandirian Masyarakat dalam Usaha-usaha Produktif}

\section{- Jamur Merang Terpadu}

Program pemberdayaan masyarakat berbasis usaha jamur merang di Desa Sukamulya, Kecamatan Cilamaya, Kabupaten Karawang mendapat respons positif. Kegiatan pengembangan jamur merang ini dirasakan oleh peserta program sangat bermanfaat dan tepat sasaran karena sesuai dengan potensi dan kebutuhan mereka.
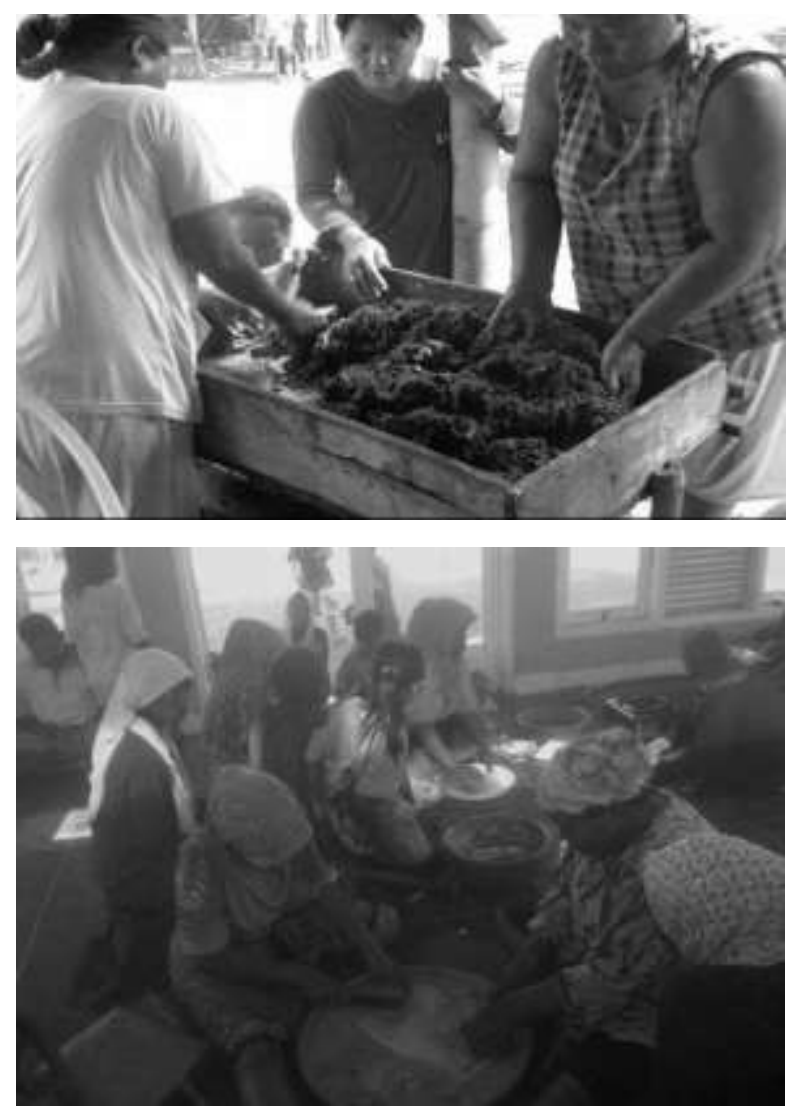

Gambar 3 Foto kegiatan pemberdayaan ibu-ibu berbasis olahan terasi. 
Warga yang telah membentuk kelompok dan pernah tidak aktif setelah difasilitasi ternyata sadar dan kembali aktif dalam membudidayakan jamur merang. Kegiatan ini memaksimalkan produktivitas warga dengan pemanfaatan potensi lokal secara optimal.

Dukungan dan antusiasme anggota kelompok tani untuk turut berpartisipasi aktif dalam penyelenggaraan program budi daya jamur merang melalui kemitraan. Hal ini sebagai hasil pendampingan yang digulirkan secara nyata direspons secara positif. Trend peningkatan produksi dan pendapatan kelompok jamur merang terpadu disajikan pada Gambar 4.

Pengembangan program jamur terpadu ini juga telah memberikan efek ganda yang positif terhadap pengembangan masyarakat lainnya. Awalnya hanya pengembangan kelompok budi daya, saat ini telah terbentuk kelompok pengolahan yang dikelola oleh ibu-ibu. Pengembangan jamur merang terpadu mempunyai dampak yang positif terhadap lingkungan. Hal ini terjadi karena melalui media jamur dapat dimanfaatkan limbah jerami sebagai media tanam. Umumnya limbah jerami di Desa Sukamulya dibakar oleh petani. Pembakaran 1 ton jerami setara menghasilkan $1.068 \mathrm{~kg} \mathrm{CO}_{2}$. Pada program budi daya jamur di Desa Sukamulya, total jerami yang dimanfaatkan sebagai media tanam jamur merang adalah 7.200 ton/ tahun. Oleh karena itu, melalui program budi daya jamur di Desa Sukamulya, PT. Pertamina Asset 3 Subang Field telah berhasil mengurangi emisi $\mathrm{CO}_{2}$ hingga $7.689 .600 \mathrm{~kg} /$ tahun.

\section{- Ternak Domba Terpadu}

Pada tahun pertama kegiatan ternak domba terpadu berada pada tahapan penyadaran dan peletakan dasar sistem pemberdayaan. Ini me-

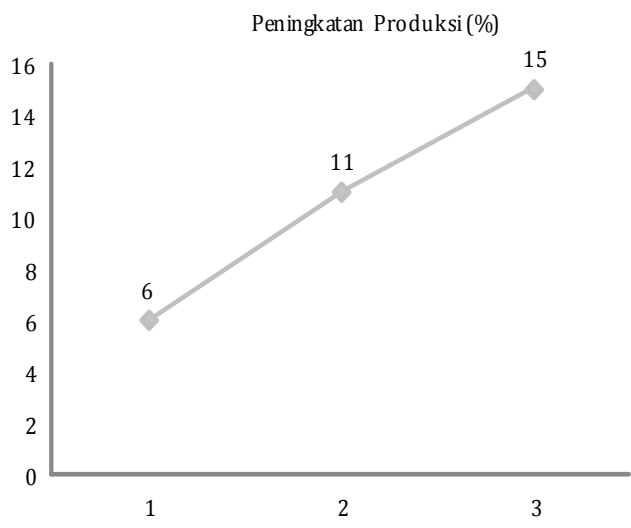

rupakan titik krusial karena menjadi dasar bagi penyelenggaraan kegiatan pada tahap selanjutnya. Pada tahap ini ada beberapa sasaran yang ingin diraih, yaitu membangun sistem manajemen usaha yang efektif dan efisien, penetapan penerima manfaat (kelompok sasaran), pengadaan ternak domba, dan fasilitas pendukung serta pembekalan penerima manfaat dengan ilmu, teknologi, dan inovasi budi daya ternak domba. Pembangunan softskill dan hardskill merupakan prioritas yang sama pentingnya dalam hal ini, karena membuka pola pikir, motivasi, dan kesadaran masyarakat dalam rangka membangun kemandirian akan sangat menentukan keberlanjutan dari program atau sistem yang telah dirancang. Keterlibatan anggota kelompok mulai dari perencanaan hingga pelaksanaan program menjadi kunci penting dalam kegiatan pemberdayaan. Pengenalan Iptek dan inovasi senantiasa memegang prinsip kearifan lokal dengan mengutamakan ketersediaan sumber daya lokal dan kemudahan implementasi dan disseminasi. Pemberian nutrisi pakan tambahan misalnya diprioritaskan dengan memanfaatakan sumber daya lokal yang tersedia dan mudah didapat seperti ampas tahu, limbah pasar, dan lainnya, merupakan contoh sederhana dari inovasi dengan mempertimbangkan sumber daya lokal. Nilai positif lain yang dirintis dalam upaya membangun kemandirian dan motiviasi penerima manfaat adalah menciptakan sumbersumber pendapatan alternatif dari usaha ternak domba misalnya dari penjualan pupuk kandang, pembuatan dan penjualan pupuk cair organik, dan kegiatan budi daya tanaman. Hal ini bertujuan menciptakan sumber-sumber penghasilan harian, mingguan, dan bulanan bagi penerima manfaat. Meski hingga saat ini nilainya masih kecil hasil evaluasi menunjukkan salah

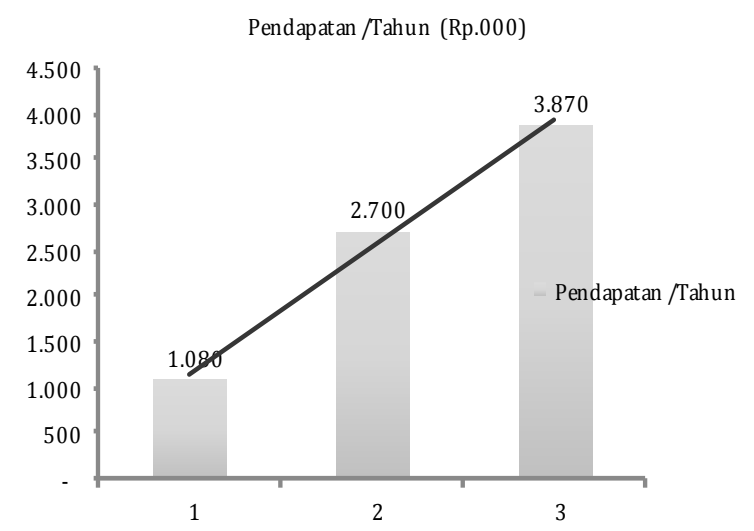

Gambar 4 Trend peningkatan produksi dan pendapatan kelompok jamur terpadu di Desa Sukamulya (PEP Asset 3 Subang Field 2013). 
satu manfaat yang dapat dirasakan langsung dari aktivitas tersebut diantaranya dalam membantu biaya operasional seperti pengadaan listrik di lokasi kandang dan pengadaan pakan tambahan bagi ternak domba.

Beberapa kendala yang ditemui sepanjang proses yang pertama adalah terjadinya pergeseran waktu pelaksanaan dari perencanaan awal. Beberapa penyebabnya antara lain keterlambatan dalam turunnya pendanaan ataupun alokasi waktu pelaksanaan beberapa kegiatan yang lebih singkat dari alokasi waktu yang ditetapkan. Tantangan lain yang ditemui adalah sulitnya membangun motivasi penerima manfaat, sehingga ketergantungan terhadap pendamping relatif tinggi. Untuk itu menjadi tugas pendamping untuk terus memotivasi anggota kelompok dalam upaya membangun kemandirian.

Program ternak domba terpadu telah memberikan contoh kepada masyarakat untuk memanfaatkan lahan secara optimal. Dalam hal ini lokasi kandang domba terpadu awalnya merupakan lahan yang kurang produktif, dan saat ini menjadi lebih produktif dengan adanya kegiatan peternakan. Melalui program ternak terpadu, juga Pertamina EP Asset 3 Subang telah berhasil menginisiasi terbangunnya kemitraan antara masyarakat, dinas teknis setempat, dan IPB serta Pertamina. Kemitraan dalam program pengembangan masyarakat menjadi hal yang sangat penting. Hal lain yang cukup positif melalui program ini adalah lokasi kandang ternak saat ini menjadi pusat kegiatan baru masyarakat setempat. Masyarakat diluar anggota kelompok bisa belajar tentang beternak, selain itu juga dengan adanya anak-anak yang bermain di kandang akan memberikan pendidikan dini tentang usaha ternak domba.

\section{- Rumah Pangan Lestari}

Pada tahun pertama kegiatan rumah pangan lestari berada pada tahapan inisiasi. Pada tahap ini ada beberapa sasaran yang ingin diraih, yaitu pembentukan kelompok, membangun kebun induk sebagai model, pengembangan depot pangan, serta pembekalan penerima manfaat dengan ilmu, teknologi, dan inovasi pemanfaatan lahan pekarangan dan pengolahan pangan. Membangun motivasi dan minat masyarakat merupakan pondasi awal dari program ini. Oleh karena itu, sosialisasi secara intensif dilakukan oleh pendamping melalui berbagai pendekatan.

Beberapa kendala yang ditemui sepanjang proses yang pertama adalah terjadinya pergeseran waktu pelaksanaan dari perencanaan awal. Beberapa penyebabnya antara lain keterlambatan dalam turunnya pendanaan dan prioritas pelaksanaan program. Tantangan lain yang ditemui adalah ketergantungan terhadap pendamping masih relatif tinggi. Untuk itu menjadi tugas pendamping untuk terus memotivasi anggota kelompok dalam upaya membangun kemandirian.

\section{- Program Jauhari Berbasis PKBM Assolahiyah}

Program Jauhari melalui pengembangan usaha terasi dan pelatihan menjahit telah memberikan manfaat nyata kepada masyarakat. Dampak ekonomi produksi usaha terasi terhadap warga masyarakat di wilayah sasaran antara lain: (1) Membuka lapangan usaha pada masyarakat dalam produksi terasi super khas Tanjung Baru sehingga mendapat tambahan pendapatan; (2) Meningkatkan harga jual bahan baku terasi dari warga masyarakat kepada pengepul lain; (3) Peningkatan pendapatan anggota mencapai Rp 300.000-600.000/bulan; (4) Peningkatan kapasitas diri melalui kemampuan calistung (membaca, menulis, dan berhitung) serta peningkatan keterampilan produksi dan budaya kerja yang mengarah pada good manufacturing production (GMP).

Saat ini PKBM telah menjadi semacam inkubator bisnis bagi warga belajar di wilayah Tanjung Baru yang berprofesi sebagai nelayan, penangkap udang rebon, dan mengolahnya menjadi terasi. Beberapa cara yang dilakukan PKBM adalah:

- PKBM menjadi sentra/bakul tempat para nelayan menjual bahan baku terasi dengan beberapa kelebihan: 1) PKBM membeli dengan standar harga yang cukup tinggi, yaitu Rp 13.000/kg pada saat musim udang. Ini jauh lebih mahal dibanding harga biasa pada saat nelayan menjual kepada pengepul/bakul lain, yaitu Rp 7.000-10.000 pada saat musim rebon; dan 2) Memberi pinjaman uang dan dibayar dengan bahan baku terasi dengan harga tetap.

- Mengangkat dan membuat brand terasi super khas Tanjung Baru sebagai oleh-oleh di tempat wisata pantai Tanjung Baru yang notabene masyarakat sekitarnya adalah pembuat terasi.

- Terasi super PKBM sudah mendapatkan legalitas produk, yaitu dengan mendapatkan izin kesehatan, sertifikat halal dari MUI, barcode, SIUP dan TDP dari BPMPT, sertifikat pendidikan, dan pelatihan keselamatan kerja 
dari Kementrian Tenaga Kerja dan Transmigrasi.

- Memasarkan terasi super khas Tanjung Baru ke level yang lebih luas agar dikenal sebagai produk khas daerah Tanjung Baru dan sebagai salah satu produk UKM unggulan Karawang cara yang dilakukan adalah memasarkan ke toko atau warung oleh-oleh di sekitar Pantura dan outlet oleh-oleh Karawang.

- Menawarkan dan menjadi langganan pemasok terasi di salah satu rumah makan terbesar di Kabupaten Karawang.

- Memasarkan melalui media online

\section{Model Inovasi dalam Pengembangan Masyarakat Secara Partisipatif}

Masyarakat melakukan usaha lebih didasarkan pada adanya pertimbangan potensi sumber daya dan kurang mempertimbangkan potensi pasar. Model pemberdayaan masyarakat secara partisipatif berorientasi pada pengolahan hasil dan kebutuhan pasar merupakan hal yang baru bagi usaha masyarakat setempat. Kegiatan pemberdayaan masyarakat secara partisipatif di Subang dan Karawang terbukti telah mendorong lahirnya inovasi-inovasi dalam usaha produktif masyarakat, pengalaman, dan pembelajaran baru bagi masyarakat sasaran. Inovasi ini berupa ide-ide, gagasan, teknologi, praktek-praktek, atau objek-objek baru yang dinilai sesuai dan diterima oleh masyarakat sasaran (Rogers \& Shoemaker 1971; Sumardjo et al. 2014). Inovasi ini tidak sekedar sebagai sesuatu yang baru, tetapi lebih luas dari itu, yakni sesuatu yang dinilai baru atau dapat mendorong terjadinya pembaruan dalam masyarakat atau pada lokalitas tertentu. Pengertian "baru" di sini mengandung makna bukan sekedar "baru diketahui" oleh pikiran (cognitive), akan tetapi juga baru karena belum diterima secara luas oleh seluruh warga masyarakat dalam arti sikap (attitude), dan juga baru dalam pengertian belum diterima dan dilaksanakan/diterapkan oleh seluruh warga masyarakat setempat (Sumardjo et al. 2014). Inovasi pemberdayaan masyarakat di Subang dan Karawang disajikan pada Tabel 3 .

Strategi keberlanjutan program yang diterapkan dalam model pemberdayaan ini adalah: (1) Secara partisipatif menganalisis potensi pasar yang menyangkut hasil olahan produk, selera konsumen, dan potensi segmen wilayah pemasaran produk usaha produktif masyarakat; (2) Berdasarkan hasil analisis pasar, secara partisipatif dikembangkan usaha produktif yang sesuai dengan minat dan potensi yang ada di masyarakat; (3) Mengembangkan inovasi tepat guna yang dilakukan berdasarkan hasil kaji

Tabel 3 Inovasi pemberdayaan masyarakat

\begin{tabular}{|c|c|}
\hline Program pemberdayaan & Inovasi/praktek baru yang diterapkan masyarakat \\
\hline \multicolumn{2}{|l|}{ A. Jamur Merang Terpadu } \\
\hline Budi daya jamur dengan media jerami & $\begin{array}{l}\text { (1) Pengembangan usaha jamur sistem kelompok, } \\
\text { (2) Pengembangan sistem zero waste, } \\
\text { (3) Pemanfaatan media jerami untuk media tanam jamur }\end{array}$ \\
\hline $\begin{array}{l}\text { Pengolahan makanan berbahan jamur } \\
\text { (mie jamur dan roti jamur) }\end{array}$ & $\begin{array}{l}\text { Pengolahan berbagai jenis makanan berbahan dasar jamur, } \\
\text { berupa mie jamur dan roti jamur yang prospektif }\end{array}$ \\
\hline \multicolumn{2}{|l|}{ B. Ternak Domba Terpadu } \\
\hline Pola usaha & $\begin{array}{l}\text { Pola budi daya kombinasi yang terdiri dari pola penggemukan } \\
\text { dan pola pembibitan untuk menghasilkan keuntungan dan jumlah } \\
\text { anakan yang cukup besar dalam waktu relatif singkat }\end{array}$ \\
\hline $\begin{array}{l}\text { Pembuatan pupuk organik cair dan } \\
\text { pupuk organik padat }\end{array}$ & $\begin{array}{l}\text { Produk yang dihasilkan dari kotoran domba yang menggunakan } \\
\text { pola fermentasi terukur dan didapatkan dari bahan-bahan/ } \\
\text { limbah organik di sekitar kandang }\end{array}$ \\
\hline $\begin{array}{l}\text { Pembuatan pakan fermentasi ber- } \\
\text { bahan baku dari jerami kering }\end{array}$ & $\begin{array}{l}\text { Penggunaan jerami yang selama ini menjadi sumber emisi akibat } \\
\text { pembakaran setelah dipotong dan penggunaan bahan sederhana } \\
\text { yang mudah didapat seperti yakult, gula, dan garam }\end{array}$ \\
\hline $\begin{array}{l}\text { Pembuatan kandang yang ramah ling- } \\
\text { kungan }\end{array}$ & $\begin{array}{l}\text { Desain kandang yang meminimalkan polusi udara (bau), pen- } \\
\text { cemaran lingkungan, dan mudah dibersihkan serta terintergrasi } \\
\text { dengan pertanian }\end{array}$ \\
\hline \multicolumn{2}{|l|}{ C. Jauhari Berbasis PKBM Assolahiyah } \\
\hline $\begin{array}{l}\text { Pembelajaran non formal berbasis } \\
\text { komunitas }\end{array}$ & $\begin{array}{l}\text { Integrasi pendidikan non formal (keaksaraan dan kesetaraan) } \\
\text { dengan pendidikan kewirausahaan. Hasil usaha dapat membiayai } \\
\text { operasional penyelengaraan pendidikan, sehingga tidak mem- } \\
\text { bebani biaya peserta pendidikan }\end{array}$ \\
\hline
\end{tabular}


bersama di antara masyarakat yang berminat dan selanjutnya dikembangkan pada masyarakat yang berminat kemudian; (4) Kepengurusan kelompok usaha sepenuhnya diserahkan dan dikelola dari, oleh, dan untuk masyarakat sesuai dengan minat dan kesiapan mereka; (5) Partisipasi masyarakat dalam pengembangan kemitraan dengan pihak pengadaan bahan baku dan pemasaran merupakan jaminan untuk keberlanjutan usaha produktif masyarakat; dan (6) Menginisiasi pembentukan koperasi sebagai wadah kegiatan usaha kelompok.

\section{SIMPULAN}

Berdasarkan aspek kemandirian, partisipasi, dan jaringan kerja pada kelompok-kelompok sasaran, maka kelompok sasaran terpesat perkembangannya adalah kelompok usaha terasi PKBM Assolahiyah. Sedangkan kelompok sasaran yang masih sangat terbatas perkembangannya adalah kelompok rumah pangan lestari. Peran para pihak sangat berpengaruh terhadap tingkat perkembangan keberhasilan kelompok sasaran. Pertamina EP berperan dalam pemberian dana stimulan. CARE LPPM IPB berperan dalam pendampingan implementasi program. Dan dinas terkait setempat berperan dalam pembinaan dan monitoring program. Pemberdayaan masyarakat yang dilaksanakan secara partisipatif melalui pendampingan terbukti efektif mendorong lahir dan berkembangnya inovasi-inovasi, serta praktek-praktek baru yang diterapkan dalam kehidupan usaha produktif masyarakat secara berkelanjutan. Keberhasilan mengembangkan partisipasi masyarakat dalam setiap kegiatan sistem bisnis usaha produktif masyarakat ternyata kunci keefektifan dalam mendorong kemandirian masyarakat. Partisipasi yang dimaksud di sini adalah dalam: (1) Membangun kerjasama yang menguntungkan; (2) Memperkuat kepercayaan di antara para pihak terkait dalam sistem bisnis usaha produktif; dan (3) Keduanya dilakukan dalam rangka menciptakan peluang meraih pendapatan melalui peningkatan nilai tambah dan posisi tawar dalam hubungannya dengan mitra. Model inovasi dalam pengembangan masyarakat secara partisipatif efektif ketika pendampingan mampu menerapkan prinsip-prinsip: (1) Partisipatif menganalisis potensi pasar hasil-hasil produk masyarakat; (2) Partisipatif dalam pengembangan usaha produktif masyarakat; (3) Pengembangan inovasi tepat guna; (4) Menempatkan masyarakat sebagai subjek dalam perencanaan, pelaksanaan, evaluasi, dan pemanfaatan hasil usaha produktif mereka; dan (5) Pengembangan kemitraan sinergis dengan para pihak dalam sistem bisnis usaha produktif berkelanjutan.

Kegiatan pendampingan agar usaha produktif berkelanjutan perlu dikembangkan nilai (value), norma, dan sistem insentif yang berkeadilan dan melembaga. Pendampingan perlu mendorong berkembangnya inovasi-inovasi yang sejalan dengan tuntutan kebutuhan pasar produk usaha produktif masyarakat. Terkait implementasi program pemberdayaan, perlu dipertahankan halhal berikut: penyelenggaraan kegiatan yang dapat meningkatkan kebersamaan, kerja sama, dan motivasi anggota program serta pengembangan kemitraan dengan pemerintah lokal ataupun stakeholders lainnya.

\section{UCAPAN TERIMA KASIH}

Tim peneliti mengucapkan terima kasih kepada: (1) PT. Pertamina Asset 3 Subang Field yang telah memfasilitasi pembiayaan program pendampingan; (2) Lembaga Penelitian dan Pengabdian kepada Masyarakat (LPPM) IPB yang telah memfasilitasi penerbitan jurnal penelitian; (3) Dinas Pertanian, pemerintah kecamatan dan desa, serta masyarakat petani dan tokoh masyarakat di lokasi penelitian di Kabupaten Karawang dan Subang yang telah membantu proses pengumpulan data di lapangan; dan (4) Tim pendamping CARE IPB di lapangan yang telah mendukung kegiatan ini.

\section{DAFTAR PUSTAKA}

Centre for Alternative Dispute Resolutions, Regulation \& Policy Analysis and Community Empowerment, Lembaga Penelitian dan Pengabdian kepada Masyarakat, Institut Pertanian Bogor (CARE LPPM IPB). 2014. Laporan Implementasi Program Ternak Domba Terpadu. PT. Pertamina EP. Asset 3 Subang Field.

Hikmat RH. 2010. Strategi Pemberdayaan Masyarakat Edisi Revisi. Humaniora Bandung (ID): Utama Press.

PT. Pertamina EP Subang Field. 2013. Keunggulan Kinerja Lingkungan dan Community Development PT. Pertamina EP. Asset 
3 Subang Field. Bahan presentasi 07 November 2013, Jakarta (ID).

PT. Pertamina EP Subang Field. 2014. Rencana Strategis Program Community Development 2014-2018.

Rogers E, Shoemaker FF. 1971. Memasyarakatkan Ide-ide Baru. Diterjemahkan oleh Abdillah Hanafi. Surabaya (ID): Usaha Nasional.

Sumardjo. 2014. Metoda Pemberdayaan Masyarakat secara Partisipatif Sebagai
Pendekatan Solusi Konflik. Bogor (ID): CARE IPB.

Sumardjo, Adi F, Leonard D, Yulia PW. 2014. Implementasi CSR Melalui Program Pengembangan Masyarakat: Inovasi Pemberdayaan Masyarakat PT. Pertamina EP. Asset 3 Subang Field. Bogor (ID): CARE IPB.

Yayasan Sekar Mandiri. 2013. Laporan Implementasi Program Jamur Merang Terpadu. PT. Pertamina EP. Asset 3 Subang Field. 